\title{
Federal Income Tax Management ${ }^{1}$
}

Josephine Turner, Michael S. Gutter, Nayda I. Torres, Horacio Soberon, and Zeynep Copur ${ }^{2}$

You can assume that there will always be some type of tax during your lifetime. Environmental

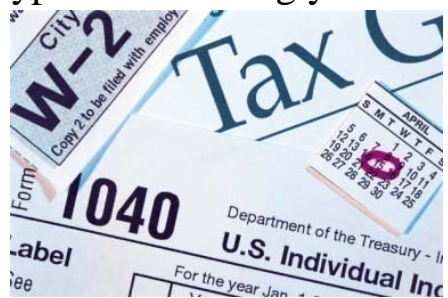

protection, decay of inner cities, educational facilities and defense spending are only a few areas in which citizens are demanding that government take action. The solution to these bad and other problems requires creative leadership, good management and a great deal of money.

Revenue to meet these needs comes primarily from taxes - sales, property, income and others. A major source of revenue comes from the federal income tax. Tax laws were created not only to raise money for government expenditures but also to encourage or discourage some behaviors. For example, tax laws encourage people to purchase homes because home owners have tax deductions available to them. On the other hand, there are heavy taxes on liquor and cigarettes to discourage excessive use.

Income tax time is stressful for many people. Ideally, enough taxes will be withheld by one's employer during the year to meet the tax due; but if additional taxes have to be paid, money must be available from the family budget. Otherwise another source must be found to pay the additional tax. If you have questions about your withholding, check with your employer. Tax management involves minimizing the effects of taxes in order to help maintain a lifestyle compatible with your goals and aspirations. It is important that you take every opportunity to minimize your tax bill.

Remember, you don't have to pay more in taxes than the law demands. Paying less in taxes by carefully planning and using the tax laws is wise and legal, but you must pay what the law requires.

If you keep records throughout the year, filing at the end of the tax year is easier. However, if the Internal Revenue Service (IRS) questions your

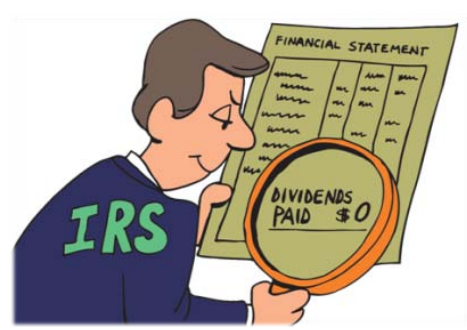
figures, the burden is on you to prove they are incorrect. The most acceptable forms of proof are your records and receipts, such as

canceled checks, vouchers, sales slips, statements of earnings, dividends and interest. If you cannot back up your figures with these or other means, you may be required to pay more taxes, as well as penalties and interest.

1. This document is FCS7026, one of a series of the Department of Family, Youth and Community Sciences, Florida Cooperative Extension Service, Institute of Food and Agricultural Sciences, University of Florida. Publication Date: November 1, 1987. Revised: March 2009. Please visit the EDIS Web site at http://edis.ifas.ufl.edu.

2. Written by Vervil Mitchell, Former Family Economics Specialist; revised by Josephine Turner, professor, Family and Consumer Economics; Nayda I. Torres, professor, Family and Consumer Economics; Michael S. Gutter, assistant professor, Family Financial Management and Haracio Soberon, former Visiting Assistant Extension Scientist, Department of Family, Youth, and Community Sciences, Institute of Food and Agricultural Sciences, University of Florida, Gainesville FL 32611. Zeynep Copur, associate professor, Family and Consumer Sciences Department, Hacettepe University, Ankara, Turkey. 


\section{Filing Advantages}

Even though some people who are employed do not have to file an income tax return because of low earnings, it may be to their advantage to file for several reasons:

- If an employer has withheld tax from your wages and the amount is more than you owe, you must file a return to get the money refunded.

- A tax advantage for low and moderately paid workers called the Earned Income Tax Credit reduces taxes owed and, if you qualify, may give you a refund even if no tax was withheld. Check with your employers to see if you are eligible for this benefit. In 2007, low- to moderate-income workers could be eligible for an Earned Income Tax Credit return up to $\$ 4,716$.

\section{Who Must File a Return}

Your filing status, age and gross income determine whether or not you have to file a return. To check whether or not you have to file, a chart is listed in the 1040EZ, the 1040A and 1040 Forms and Instruction booklets. If you did

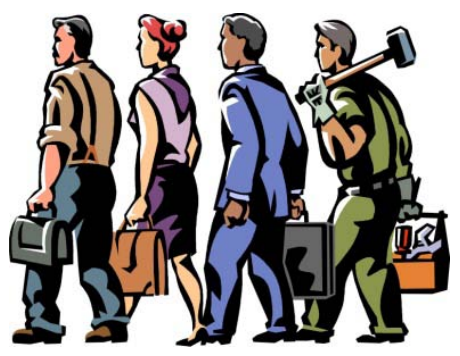
not receive the forms you can visit the IRS Web site at http://www.irs.gov or call 1-800-8291040.

Forms 1040EZ and 1040A can be used for low to moderate incomes if you meet the guidelines. These forms are simpler and can be completed in a shorter time and with fewer calculations but you must fall within the specified guidelines found in the instruction pages. In some cases, even if one does qualify to use the simpler forms, it may be to your advantage to file the 1040 form. For example, if your charitable giving is greater than the standard deduction allowed on 1040EZ or 1040A, you can use a Schedule A with the 1040 form to reduce your adjusted gross income. If you qualify for Head of Household filing status, using 1040A or 1040, may result in a lower tax than filing the Single filing status on 1040EZ. The following information refers to the 1040 form:

Filing Status. A taxpayer's filing status is determined by his/her marital status on December 31 of the tax year. Married people can file one joint return or they may each file separately.

Depending on specific circumstances, unmarried taxpayers may be classified as Single, Head of Household (unmarried person who paid over half of the cost of keeping up a home for qualified live-in dependents such as minor children or elderly parents), or Qualifying Widow(er) (person whose spouse has died during one of the previous tax years and has a child living with him/her whom he/she can claim as a dependent).

Age. Along with filing status in determining if one must file a return, whether or not a person is over or under age 65 is a consideration.

Gross Income. The last part of the filing formula is the gross income of the taxpayer. Therefore, it is important to know what is included in or excluded from gross income.

- Wage/Salary. The employee’s gross income includes wages, salaries, commissions, bonuses, tips and income from second jobs. Generally the IRS will not tax the cost of most fringe benefits. By January 31 each year, your employer must give you a $\mathrm{W}-2$ form showing your total earnings for the previous year and the amounts withheld for taxes and other purposes. Attach a copy of your W-2 to your income tax form. If you are paid on a commission basis, your employer will send you a 1099 form. 
- Unemployment Compensation. All unemployment benefits are taxable.

- Interest Income. Most interest income, received by the taxpayer, must be reported as income. By January 31 each year, the bank or other institution that holds your savings account will send you a 1099 Form showing your earned interest for the year.

- Dividends. If you own stocks, you will receive a year-end statement of dividends paid to you, either from your brokerage firm if it holds your stock, or directly from the issuing company if you hold the stock yourself.

- Capital Gains and Losses. Capital gains or losses are your profits or losses from the sale of any property you own and use for personal purposes or investments.

- Rents. All of your income and expense records (such as taxes, interest and depreciation) for rental property should be kept separately from records for property that you use yourself.

- Pensions. At the end of the year, your pension fund trustee will send you copies of either (or both, if necessary) $\mathrm{W}-2 \mathrm{P}$ Form for pension and certain other periodic payments or 1099-R form for lump sum distributions. In addition, your former employer will send you annual statements breaking down benefits paid to you in taxable and nontaxable portions.

- Alimony. Alimony is taxable as regular income. Child support payments are neither taxable if received, nor deductible if paid.

- Social Security. A portion of your Social Security benefits may be taxable. Check the instructions on Form 1040 details.
Non-taxable income does not have to be reported. Examples of non-taxable income include the following:

$\checkmark \quad$ Child support payments received

$\checkmark$ Life insurance death benefits

$\checkmark$ Divorce settlements (lump sum)

$\checkmark$ Money from lawsuits for accidents

$\checkmark$ Gifts and inheritances

$\checkmark$ Workers compensation

$\checkmark$ Income from municipal bonds

$\checkmark \quad$ Value of food stamps

$\checkmark$ Proceeds from sale of personal items sold for less than purchase price - such as in garage sales

$\checkmark$ Veteran benefits

$\checkmark$ Part of Social Security benefits

$\checkmark$ Employer-provided benefits - up to specific limits

There are some expenses, such as moving costs, which you can deduct from your gross income. These are called adjustments to gross income. Your adjusted gross income (AGI) is your gross income less your adjustments to income. The AGI is used to determine eligibility for many tax breaks including personal exemptions, itemized deductions, and credits. Higher AGI may have reduced benefits.

\section{Examples of adjustments to income:}

Contributions to qualified retirement plans such as IRA's, Keough, or SEP

$\checkmark$ Moving expenses (restricted)

$\checkmark \quad$ Alimony paid

$\checkmark \quad 1 / 2$ of self-employment tax

$\checkmark$ Penalty for early withdrawal of CD’s

$\checkmark$ Medical savings account deduction

$\checkmark$ Self-employed health insurance deduction 


\section{Itemized Deductions}

Deductions are expenditures that you made during the year that can be subtracted from your adjusted gross income. The tax laws specify which expenses are deductible. Note you must choose between the Standard Deduction and Itemized Deductions. Once you know your total Itemized Deductions, you compare this to the Standard Deduction provided on form 1040. Use whichever is greater.

Examples of tax deductible expenses which may be itemized on Schedule A:

1. Mortgage interest

2. Gifts to charity (50\% Ceiling)

3. State and local income taxes

4. Property taxes

5. Job expenses (2\% Floor)

6. Medical expenses (7.5\% Floor)

7. Casualty and theft losses (10\% Floor)

The expenses labeled with floor or ceiling have built-in limits as to how much of the expenses may be deducted. This often tied to AGI. The percentages indicate a floor or ceiling relative to Adjusted Gross Income (AGI). A ceiling represents a maximum. A floor represents a minimum level of expense. For instance, out of pocket medical expenses in excess of $7.5 \%$ of AGI may be deducted, but the amount less than this cannot. ${ }^{6}$ The amount deducted for charitable gifts cannot exceed $50 \%$ of AGI. ${ }^{2}$ Expenses that you have to pay for your job, but are not reimbursed and exceeding $2 \%$ of AGI may be included. ${ }^{5}$ Losses resulting from casualty or theft, not reimbursed by insurance and in excess of $10 \%$ of AGI, may be included as an itemized deduction. ${ }^{7}$ Many taxpayers do not have a large amount of deductible expenses. They would use the standard deduction shown on each tax form. The amount of the standard deduction depends on the filing status of the taxpayer. In addition, the standard deduction increases if the taxpayer and/or spouse are blind or if either or both are 65 or over.
Taxpayers should take time to do the math to find whether taking the standard deduction or itemizing deductible expenses will result in a greater deduction from the adjusted gross income. Personal exemptions - you can deduct a personal exemption for every person in your household that can be claimed as a dependent, including you and your spouse. If an individual is eligible to be claimed as a dependent on another's return, he cannot take a personal exemption on his own return. An example of this is when a child is claimed as a dependent on a parent's return, the child is then unable to claim a personal exemption against his/her own income.

\section{Income Tax Rates and Computation}

Currently there are six basic income tax rates: $10 \%, 15 \%, 25 \%$, 28\%, 33\%, and 35\%. The rates that apply to you depend on your taxable income and on your filing status. These tax rates are called tax brackets.

A common misconception about taxes is that if your taxable income increases so that you are pushed into a higher bracket, you will end up with a lower "take home" income. The way taxes are computed does not allow this to happen because the tax rates are applied in income steps. Only the additional income is taxed in the higher bracket. The lower part of your earnings will still be taxed at the lower rate. For example:

A single taxpayer with a taxable income of $\$ 35,000$ paid \$5,174 in taxes in 2007. The tax rate bracket for $\$ 30,000$ is $25 \%$. This taxpayer is in the 25\% tax bracket, but the first \$31,850 of his/her income was taxed at the lower $15 \%$ rate. The remaining \$3,150 is taxed at $25 \%$.

Most people do not have to compute taxes themselves; instead they can use the tax tables provided with the tax forms to determine the tax due. These tables have been calculated using the procedure discussed above. 


\section{Credits}

After the tax has been determined, you may qualify for additional credits, such as child and dependent care expenses, credit for the elderly or disabled and/or adoption credit. Credits are deducted dollar for dollar from taxes due. Deductions, on the other hand, reduce your tax at your marginal tax rate.

\section{Other Taxes}

There are also certain other taxes which, if they apply to your situation, must be added to the tax - such as self-employment tax, Social Security and Medicare, tip income not reported to the employer, tax on qualified retirement plans, advanced Earned Income Credit payments and household employment taxes.

\section{Payment}

After any credits have been deducted and other taxes added to the computed tax amount, deduct the withholding payments found on your $\mathrm{W}-2$ form(s) and Earned Income Tax Credits (if you qualify), to find the amount of tax you owe or the refund due to you.

\section{Preparing Your Return}

You can easily complete your return if you keep good records and your financial activities are not complicated. If you need it, free help is available.

1. The IRS will provide you with many resources without charge:

- IRS office - for advice, forms, instructions and help filling out forms.

- IRS Web site (at http://www.irs.gov) for forms, instructions, publications and educational material.

- $\quad$ Phone - call 1-800-829-1040 for advice.

2. Many of the forms, instructions or publications are available at your local library or from www.irs.gov. The IRS Web site allows you to search for and see the forms to determine which form you will need.

3. Tax preparation software is available at local computer retailers, discount stores or through various Web sites over the Internet.

4. In some communities, there is often free help available from trained volunteer groups such as the AARP Tax-Aide group. These sites are known as Volunteer Income Tax Assistance or VITA sites.

If you decide you do not want to prepare the return yourself, commercial tax services are available. Their fees range from around \$30 up to $\$ 150$ or more depending on the complexity of the return and the qualification of the tax preparers. Ask for a general estimate or take all of your records to the preparer's office and ask for a firm quote. Be sure to ask what liability the preparers will assume, for example, if they will pay any penalties and interest if they make mistakes.

Check to see

if the preparers are licensed to fill out the return. Be wary of tax preparation

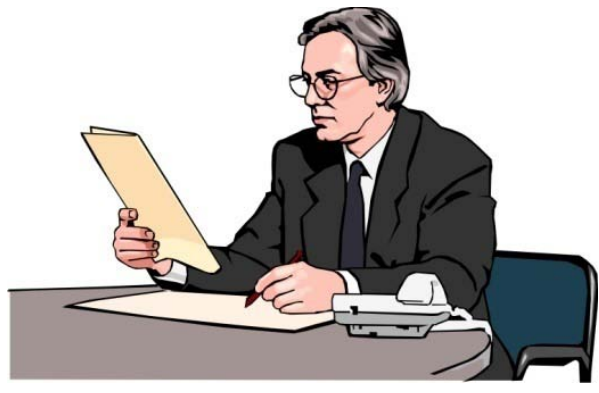

services that promise a quick refund. The fee that you pay for this service can be substantial. A quick refund is a loan made to you that is secured by your tax refund. These loans have an APR interest rate of about $400 \%$. Instead, you can file electronically and supply your bank account number and receive your refund in less than 10 days.

Also, be wary of firms that promise or guarantee a refund. No reputable tax preparer can promise such a thing before they have had a chance to look at your individual records. If a tax preparer cheats on your behalf, you are still responsible THINK ABOUT IT! Having someone else even the IRS - complete your return does not relieve you of the responsibility for the accuracy of your return. 


\section{Ways to file}

1. Mail - Complete your return and mail it to the IRS in the envelope provided or send it to the address for your state found in the instruction manual.

\section{Electronically}

- If you have a modem, computer and tax software, you can e-file your return from home. Through a tax transmitter, you can file 24 hours a day, seven days a week. A tax transmitter may charge a fee for transmitting your return.

- Tax Professionals. You can prepare your own return and have a professional transmit it electronically or have your return prepared and transmitted. Look for the "AUTHORIZED IRS E-FILE PROVIDER” sign. Tax professionals may charge a fee and fees may vary depending on the professional and the services. Be sure to ask what the fee is before you request the service.

- Some employers or financial institutions offer e-file free or for a small fee to their employees or customers.

3. Phone - If you received a TeleFile Tax Package in the mail, you are eligible to file your return by using your Touch-Tone phone.

\section{Records to Keep}

Be sure to keep all the records that you used to file your income tax return. If the IRS audits a return, they will ask to see these records.

\section{Income Records}

Keep your copy of all the W-2 or 1099 forms you and your spouse received from employers for wages, salaries, commissions, bonuses, and tips.

Unemployment compensation statement or check stubs.
1099 forms for interest or dividend income received.

All records to verify capital gains or losses.

Records of income and expense for rental properties. Keep separate from your home.

Annual statements from pensions and/or Social Security.

Statement of alimony received.

\section{Expense Records}

Year-end statements which show interest paid on your mortgage.

Receipts and canceled checks for charitable contributions.

Receipts for taxes paid - real estate, state and local income taxes.

Receipts for qualified medical expenses, job-related expenses, and casualty and theft losses.

\section{How Long to Keep Records}

Keep a copy of your records, as well as copies of previous tax returns, for at least 3 years but possibly up to 10 years or until the statute of limitations for that return runs out. However, in instances of fraud or securities transactions, these may not face time limits--keeping a permanent file of tax records is recommended. The statute of limitations is the period of time in which you can amend your return to claim a credit or refund or the IRS can assess additional tax.

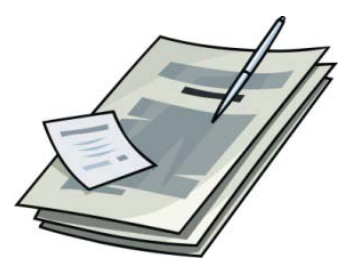

Save the following documents for three years: canceled checks, insurance claims, travel diaries, receipts, sales slips, invoices and medical bills. 
You should keep these records permanently: complete copies of previous tax returns, proof of when you bought and sold investments, all records of real estate or personal property, and divorce decrees or separation agreements that justify alimony or child-support payments.

Table 1. Period of Limitations

\begin{tabular}{|c|c|c|}
\hline & If you... & $\begin{array}{l}\text { THEN the } \\
\text { period is... }\end{array}$ \\
\hline 1 & $\begin{array}{l}\text { Owe additional tax and (2), } \\
\text { (3), and (4) do not apply to } \\
\text { you }\end{array}$ & 3 years \\
\hline 2 & $\begin{array}{l}\text { File a claim for credit or } \\
\text { refund after you filed your } \\
\text { return }\end{array}$ & $\begin{array}{l}\text { Later of } 3 \text { years } \\
\text { or } 2 \text { years after } \\
\text { tax was paid }\end{array}$ \\
\hline 3 & $\begin{array}{l}\text { Do not report income that } \\
\text { you should and it is more } \\
\text { than } 25 \% \text { of the gross } \\
\text { income shown on your } \\
\text { return }\end{array}$ & 6 years \\
\hline 4 & $\begin{array}{l}\text { File a claim for a loss from } \\
\text { worthless secures }\end{array}$ & 7 years \\
\hline 5 & File a fraudulent return & No limit \\
\hline 6 & Do not file a return & No limit \\
\hline
\end{tabular}

\section{Filing an Amended Return}

Sometimes a mistake has been made on a previous return. The IRS permits you to file a corrected return using Form 1040X. The mistake may mean you owe more or that you are entitled to a larger return. You should file in either case. It's better to own up to a mistake than face an audit later. Taxpayers have three years from the original filing date to do this. Families that forgot to claim certain credits such as the Earned Income Tax Credit should definitely do this.

\section{Minimize Your Taxes}

- Take advantage of the Earned Income Tax Credit if you qualify.

- Take advantage of employer-provided benefits.

- For homeowners, interest paid on a mortgage and real estate taxes are deductible if you itemize on Schedule A.

- Contribute to your retirement by contributing to an Individual Retirement Account. Contributions may qualify as adjustments to income and, remember, ROTH IRA earnings are tax-free.

- Take advantage of the tax credit available for day care for dependents if you qualify.

\section{Getting Help}

(:) Residents of many communities in Florida may be close to a Volunteer Income Tax Assistance (VITA) Site. These sites provide free tax preparation and filing for many eligible Florida.

(:) IRS Hotline for questions about your return is (800) 829-1040.

(:) Florida Residents may also call their local IRS office; this can be found on IRS.gov or local phone directory.

Those needing taxpayer advocacy service in Florida can call either (904) 665-1000 (Jacksonville) or (954) 423-7677(Plantation)

\section{References}

1. Garman, E. Thomas and Forgue, Raymond E. 2006. Personal Finance $8^{\text {th }}$ Edition. New York: Houghton Mifflin Co.

2. WwW.IRS.gov/ 
Table 2: Earned Income Tax Credit: Are You Eligible?

\begin{tabular}{|c|c|c|c|c|}
\hline \multicolumn{2}{|c|}{$\begin{array}{l}\text { First, you must meet all the rules in this } \\
\text { column. }\end{array}$} & \multicolumn{2}{|c|}{$\begin{array}{l}\text { Second, you must meet all the rules in one of } \\
\text { these columns, whichever applies. }\end{array}$} & \multirow{2}{*}{\begin{tabular}{|l} 
Third, you must \\
meet the rule in this \\
column
\end{tabular}} \\
\hline Rule & for everyone & $\begin{array}{l}\text { Rules if you have a } \\
\text { qualifying child }\end{array}$ & $\begin{array}{c}\text { Rules if you do not } \\
\text { have a qualifying } \\
\text { child }\end{array}$ & \\
\hline $\begin{array}{l}\text { 1. Your adjusted } \\
\text { gross income } \\
\text { (AGI) must be } \\
\text { less than: } \\
\mathbf{- \$ 3 8 , 6 4 6} \\
\text { (\$41,646 for } \\
\text { married filing } \\
\text { jointly) if you } \\
\text { have more } \\
\text { than one } \\
\text { qualifying } \\
\text { child, } \\
\text {-\$33,995 } \\
\text { (\$36,995 for } \\
\text { married filing } \\
\text { jointly) if you } \\
\text { have one } \\
\text { qualifying } \\
\text { child, or } \\
\mathbf{- \$ 1 2 , 8 8 0} \\
\text { (\$15,880 for } \\
\text { married filing } \\
\text { jointly) if you } \\
\text { do not have a } \\
\text { qualifying } \\
\text { child. }\end{array}$ & $\begin{array}{l}\text { 5. You cannot file Form } \\
2555 \text { or Form } 2555-E Z \\
\text { (relating to foreign } \\
\text { earned income) } \\
\text { 6. Your investment } \\
\text { income must be } \\
\$ 2,950 \text { or less. } \\
\\
\text { 7. You must have earned } \\
\text { income (wages, } \\
\text { salaries, tips, and } \\
\text { other taxable } \\
\text { employee pay, or net } \\
\text { earnings from self- } \\
\text { employment, or gross } \\
\text { income received as a } \\
\text { statutory employee). }\end{array}$ & $\begin{array}{l}\text { 8. Your child must meet } \\
\text { the relationship, age } \\
\text { and residency tests. } \\
\text {-Your son, daughter, } \\
\text { stepchild, foster child, or } \\
\text { a descendant of any of } \\
\text { them, or brother, sister, } \\
\text { half brother, half sister, } \\
\text { step brother, stepsister, } \\
\text { or a descendant of any } \\
\text { of them, } \\
\text {-under age } 19 \text { at the end } \\
\text { of the year, } \\
\text {-under age } 24 \text { at the end } \\
\text { of the year and a } \\
\text { student, or } \\
\text {-permanently and totally } \\
\text { disabled at any time } \\
\text { during the year, } \\
\text { regardless of age, } \\
\text {-lived with you in the } \\
\text { U.S. for more than half } \\
\text { of the year. } \\
\text { - Your qualifying child } \\
\text { must have a valid SSN. }\end{array}$ & $\begin{array}{l}\text { 12. You cannot be } \\
\text { dependent of } \\
\text { another person. } \\
\text { 13. You cannot be a } \\
\text { qualifying child } \\
\text { of another } \\
\text { person. }\end{array}$ & $\begin{array}{l}\text { 15. Your earned } \\
\text { income must be } \\
\text { less than: } \\
\text {-\$38,646 } \\
\text { (\$41,646 for } \\
\text { married filing } \\
\text { jointly) if you } \\
\text { have more than } \\
\text { one qualifying } \\
\text { child, } \\
\mathbf{- \$ 3 3 , 9 9 5} \\
\text { (\$36,995 for } \\
\text { married filing } \\
\text { jointly) if you } \\
\text { have one } \\
\text { qualifying child, } \\
\text { or } \\
\mathbf{- \$ 1 2 , 8 8 0} \\
\text { (\$15,880 for } \\
\text { married filing } \\
\text { jointly) if you do } \\
\text { not have a } \\
\text { qualifying child. }\end{array}$ \\
\hline
\end{tabular}

You can use an EIC Calculator at IRS.gov 